\title{
Management of Pregnant Women with Invasive Cervical Cancer about Ten Cases
}

\author{
K. Diabaté*, H. Bakkali, A. Lachgar, S. Nadir, T. Kebdani, B. K. El Gueddari, N. Benjaafar \\ Radiotherapy Department, National Institute of Oncology Mohamed V University, Rabat, Morocco \\ Email: *diabatekoniba2006kd@yahoo.fr
}

How to cite this paper: Diabaté, K., Bakkali, H., Lachgar, A., Nadir, S., Kebdani, T., El Gueddari, B.K. and Benjaafar, N. (2018) Management of Pregnant Women with Invasive Cervical Cancer about Ten Cases. Journal of Cancer Therapy, 9, 740-754. https://doi.org/10.4236/jct.2018.99061

Received: August 13, 2018

Accepted: September 16, 2018

Published: September 19, 2018

Copyright () 2018 by authors and Scientific Research Publishing Inc. This work is licensed under the Creative Commons Attribution International License (CC BY 4.0).

http://creativecommons.org/licenses/by/4.0/

\begin{abstract}
The purpose of this study was to update the management of invasive cervical cancers diagnosed during pregnancy. Patients and methods: This study was performed retrospectively at radiotherapy department of National Institute of Oncology Rabat Morocco. From 01/04/2005 to 31/05/2010, ten patients with invasive cervical cancer during pregnancy were included. Results: Ten patients were included in the study. The staging was as follow: stage IIIB $(\mathrm{n}=4)$; stage IIB $(\mathrm{n}=2)$ and stage IB2 $(\mathrm{n}=4)$. The radical abdominal hysterectomy with pelvic lymphadenectomy was performed in five patients; a therapeutic interruption of pregnancy was performed in four patients. One pregnancy has resulted in the birth of a living child (by cesarean section). Adjuvant treatment was concomitant chemoradiotherapy followed by low dose rate (LDR) brachytherapy in three patients; adjuvant concomitant chemoradiotherapy followed by high dose rate (HDR) brachytherapy was performed in four patients; a HDR brachytherapy was done in one patient. Two patients have received an exclusive external radiotherapy. After a median follow-up of 4 years ( 2 - 7 years), there were bone and lung metastases in one patient. Nine patients are alive after completed treatment. Conclusion: Our series focused on ten patients with invasive cervical cancer during pregnancy. Management is complex and requires discussion in a multidisciplinary meeting. Routine screening of cervical cancer and awareness are the key point to improve the treatment and survival rate of patients. The management of all cases is according to international recommendations.
\end{abstract}

\section{Keywords}

Cervical Cancer, Pregnancy, Treatment

\section{Introduction}

Cervical cancer during pregnancy is a rare situation; this malignant tumor is one 
of the most commonly diagnosed cancers during pregnancy (with hematologic malignancy, breast cancer and melanoma). Its incidence, according to the populations, varies between one and ten per 10,000 pregnancies [1]. There are few data available in Africa. These are mostly women with high parity (four to five depending on the studies) [2] [3], patients treated during pregnancy and in immediate postpartum are sometimes mixed. There is no currently repository available for the management of invasive cervical cancer during pregnancy. This management depends on the stage (and tumor size), the histological type of the tumor, the term of pregnancy and the desire of the couple to maintain pregnancy. The low frequency of this situation did not permit randomized studies. According to a recent Swedish study, $1.2 \%$ of invasive cervical cancers are discovered during pregnancy [4]. Zemlickis et al. [5] showed that cervical cancers diagnosed during pregnancy were significantly early stages. Stage I: $69 \%-83 \%$ versus $42 \%$ in the non-pregnant group; stage II: $11 \%-23 \%$ versus $35 \%$; stage III: $3 \%-8 \%$ versus $21 \%$ and stage IV: $0 \%-3 \%$ versus $2 \%$. About invasive cervical cancer diagnosed during pregnancy, Morice et al. published national recommendations [6]. These recommendations are validated by three French learned societies: French Society of Gynecologic Oncology; French Society of Pelvic Surgery and the National College of French Gynecologists and Obstetricians. We conducted a review of the literature to update the management of invasive cervical cancers diagnosed during pregnancy.

\section{Patients and Methods}

It was a retrospective study from 01/04/2005 au 31/05/2010. We included pregnant patients with confirmed cervical cancer. We obtained a clear consent from patients before inclusion.

Non-pregnant patients with cervical cancer were excluded. Patients were grouped according to the age of pregnancy, the histological type, tumor size, and the classification of the International Federation of Gynecology and Obstetrics. We have analyzed the clinical, pathological and therapeutic features of the patients. The treatment was (radical abdominal hysterectomy with pelvic lymphadenectomy or concomitant radiochemotherapy or exclusive radiotherapy or brachytherapy). The simulation was done at CT scan. Radiotherapy was administered with linear accelerator $18 \mathrm{MV}$; the concomitant chemotherapy was cisplatin $40 \mathrm{mg} / \mathrm{m}^{2} /$ week. Brachytherapy with FLEXITRON V3 projector. Data was analyzed on SPSS version 20 (SPSS Inc., Chicago, IL).

\section{Results}

\subsection{Characteristics of the Patients}

Ten patients were included. The median age was 32 years old (range 21 - 35), all the patients were multiparous, and the average of the pregnancies was 18.6 weeks of gestation (WG). Clinical aspects were dominated by spontaneous bleeding with leucorrhea and pelvic pain. The patients had no pathological an- 
tecedents or notions of gynecological follow-up. The biopsy had objectified squamous cell carcinoma in eight cases, adenocarcinoma in two patients. The diagnosis of cancer was made in the first quarter in nine cases and in the third quarter in one case. The median time to diagnosis was 2 months (range 1 - 9) (Table 1).

The extension work up consisted on an abdominal and pelvic ultrasound performed in all patients. Magnetic resonance imaging (MRI) was performed in one patient at 10 weeks of gestation. Abdominal and pelvic CT scan was performed after Radical abdominal hysterectomy with pelvic lymphadenectomy in five patients and after therapeutic interruption of pregnancy in four patients; this CT scan had objectified pelvic lymph node involvement in three patients. Chest $\mathrm{X}$ ray was performed in nine patients (five patients after hysterectomy; four patients after therapeutic interruption of pregnancy and in a patient after cesarean section). The patients were classified, according to the classification of International Federation of Gynecology and Obstetrics (FIGO) 2002 in stage IIIB ( $\mathrm{n}=$ 4) $40 \%$, IIB $(n=2) 20 \%$ and stage IB2 $(n=4) 40 \%$.

\subsection{Therapeutic Care}

Nine were sent by regional centers and had already undergone surgery after informed consent: Five patients had undergone radical abdominal hysterectomy with pelvic lymphadenectomy, adjuvant therapy in these patients was in case 3 , HDR vaginal brachytherapy with tandem and cylinder applicator at the dose of 3 weekly sessions of $7 \mathrm{~Gy}$ prescribed at $0.5 \mathrm{~cm}$ from the surface of the applicator. In four patients (cases $1,4,8,9$ ), adjuvant therapy included external beam radiotherapy by photons $\times 25 \mathrm{MV}$ at the dose of $46 \mathrm{~Gy}$ in 2 Gy per fraction in five sessions per week associated with concomitant cisplatin $40 \mathrm{mg} / \mathrm{m}^{2}$ per week; then the complement by HDR brachytherapy in 2 weekly sessions of 7 Gy prescribed at $0.5 \mathrm{~cm}$ from the surface of the applicator (See Table 1). Four patients diagnosed between 8-11WG (Cases 5, 6, 7 and 10), had benefited after therapeutic interruption of pregnancy; exclusive external beam radiotherapy at a dose of 70 Gy in 2 Gy per fraction and 35 fractions in patient $\mathrm{N}^{\circ} 7$ (reason the detection of kidney failure, which is a contraindication of chemotherapy with cisplatin, there was also no reduction in tumor size after). In the other three patients (cases 10, 5 and 6), the treatment was external beam radiotherapy photons $\times 25 \mathrm{MV}$ at the dose of $46 \mathrm{~Gy}$ in $2 \mathrm{~Gy}$ per fraction in five sessions per week associated with concomitant cisplatin $40 \mathrm{mg} / \mathrm{m}^{2}$ per week; then the complement by LDR brachytherapy at the dose of $24 \mathrm{~Gy}$, the source used was cesium 137. Calculation of dose distribution was based on recommendations of International Commission on Radiation Units and measurements (ICRU) 38.

In patient $\mathrm{N}^{\circ} 2$, the cancer is diagnosed during pregnancy at $39 \mathrm{WG}$, resulted in the birth of a child living by cesarean section. Lymph node dissection performed during cesarean section was positive, exclusive external beam radiotherapy at a dose of $70 \mathrm{~Gy}$ in 2 Gy per fraction and 35 fractions was adjuvant treatment (reason was the detection of kidney failure). 
Table 1. Regroup patients according the age of the patient, age of pregnancy, histological type, size at diagnosis, stage (initial IFOG) treatment, histology, the delay diagnostic-treatment.

\begin{tabular}{|c|c|c|c|c|c|c|c|c|c|c|}
\hline 窧 & 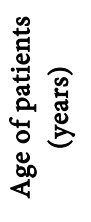 & 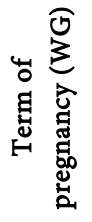 & 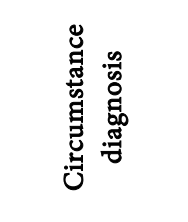 & 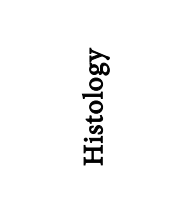 & 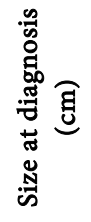 & 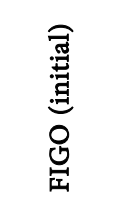 & 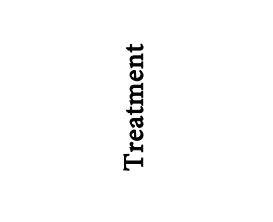 & 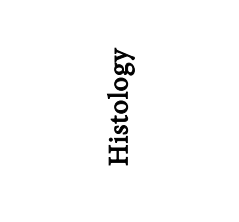 & 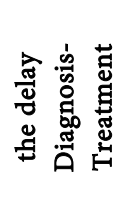 & 起 \\
\hline $\begin{array}{c}1 \\
(2005)\end{array}$ & 31 & 11 & $\begin{array}{l}\text { spontaneous } \\
\text { and post coital } \\
\text { metrorrhagia }\end{array}$ & $\begin{array}{c}\text { Moderately } \\
\text { differentiated } \\
\text { squamous }\end{array}$ & $>4$ & IB2 & $\begin{array}{l}\text { 1) TIP by laparotomy } \\
\text { 2) concomitant } \\
\text { radio-chemotherapy } \\
46 \mathrm{~Gy}, 2 \mathrm{~Gy} / \mathrm{fr}+ \\
\text { cisplatin } 40 \mathrm{mg} / \mathrm{m}^{2} \\
\text { and brachytherapy } \\
24 \mathrm{~Gy}\end{array}$ & $\begin{array}{l}\mathrm{N}(\mathrm{p})+ \\
\mathrm{N}(\mathrm{Ao})-\end{array}$ & 5 weeks & 84 \\
\hline $\begin{array}{c}2 \\
(2007)\end{array}$ & 33 & 39 & $\begin{array}{l}\text { spontaneous } \\
\text { and post coital } \\
\text { metrorrhagia }\end{array}$ & $\begin{array}{c}\text { Moderately } \\
\text { differentiated } \\
\text { squamous }\end{array}$ & 5 & IIIB & $\begin{array}{l}\text { 1) cesarean at } 39 \mathrm{WA} \\
\text { 2) external RTH } \\
70 \mathrm{~Gy}, 2 \mathrm{~Gy} / \mathrm{fr}\end{array}$ & $\begin{array}{c}\mathrm{N}(\mathrm{p})+ \\
\mathrm{N}(\mathrm{Ao})-\end{array}$ & 8 weeks & 60 \\
\hline $\begin{array}{c}3 \\
(2007)\end{array}$ & 31 & 10 & $\begin{array}{l}\text { spontaneous } \\
\text { and post coital } \\
\text { metrorrhagia }\end{array}$ & $\begin{array}{c}\text { Moderately } \\
\text { differentiated } \\
\text { ADK }\end{array}$ & $>4$ & IB2 & $\begin{array}{l}\text { 1) TIP by laparotomy } \\
\text { 2) brachytherapy } \\
\text { HDR } 3 \times 7 \text { Gy }\end{array}$ & $\begin{array}{c}\mathrm{N}(\mathrm{p})- \\
\mathrm{N}(\mathrm{Ao})-\end{array}$ & 3 weeks & 60 \\
\hline $\begin{array}{c}4 \\
(2008)\end{array}$ & 21 & 8 & $\begin{array}{l}\text { spontaneous } \\
\text { metrorrhagia + } \\
\text { loss whitish }\end{array}$ & $\begin{array}{c}\text { Moderately } \\
\text { differentiated } \\
\text { ADK }\end{array}$ & $>4$ & IB2 & $\begin{array}{l}\text { 1) TIP by laparotomy } \\
\text { 2) concomitant } \\
\text { radio-chemotherapy } \\
46 \mathrm{~Gy}, 2 \mathrm{~Gy} / \mathrm{fr}+ \\
\text { cisplatin } 40 \mathrm{mg} / \mathrm{m}^{2} \\
\text { and brachytherapy } \\
\text { HDR } 2 \times 7 \mathrm{~Gy}\end{array}$ & $\begin{array}{c}\mathrm{N}(\mathrm{p})-\text { and } \\
\text { insufficient } \\
\mathrm{N}(\mathrm{Ao})-\end{array}$ & 2.5 weeks & 48 \\
\hline $\begin{array}{c}5 \\
(2008)\end{array}$ & 35 & 11 & $\begin{array}{l}\text { spontaneous } \\
\text { and post coital } \\
\text { metrorrhagia }\end{array}$ & $\begin{array}{c}\text { differentiated } \\
\text { squamous } \\
\text { little }\end{array}$ & 6 & IIIB & $\begin{array}{l}\text { 1) TIP } \\
\text { 2) concomitant } \\
\text { radio-chemotherapy } \\
46 \mathrm{~Gy}, 2 \mathrm{~Gy} / \mathrm{fr}+ \\
\text { cisplatin } 40 \mathrm{mg} / \mathrm{m}^{2} \\
\text { and brachytherapy } \\
\text { LDR } 24 \mathrm{~Gy}\end{array}$ & $\begin{array}{c}\text { No } \\
\text { lymphadenectomy }\end{array}$ & 3 weeks & 48 \\
\hline $\begin{array}{c}6 \\
(2008)\end{array}$ & 32 & 8,6 & $\begin{array}{l}\text { spontaneous } \\
\text { and post coital } \\
\text { metrorrhagia }\end{array}$ & $\begin{array}{c}\text { Moderately } \\
\text { differentiated } \\
\text { squamous }\end{array}$ & 7 & IIIB & $\begin{array}{l}\text { 1) TIP } \\
\text { 2) concomitant } \\
\text { radio-chemotherapy } \\
46 \mathrm{~Gy}, 2 \mathrm{~Gy} / \mathrm{fr}+ \\
\text { cisplatin } 40 \mathrm{mg} / \mathrm{m}^{2} \\
\text { and brachytherapy } \\
\text { LDR } 24 \mathrm{~Gy}\end{array}$ & $\begin{array}{c}\text { No } \\
\text { lymphadenectomy }\end{array}$ & 3 weeks & 48 \\
\hline $\begin{array}{c}7 \\
(2009)\end{array}$ & 34 & 10 & $\begin{array}{l}\text { spontaneous } \\
\text { and post coital } \\
\text { metrorrhagia }\end{array}$ & $\begin{array}{c}\text { Moderately } \\
\text { differentiated } \\
\text { squamous }\end{array}$ & 6 & IIIB & $\begin{array}{l}\text { 1) TIP } \\
\text { 2) external RTH } \\
70 \mathrm{~Gy}, 2 \mathrm{~Gy} / \mathrm{fr}\end{array}$ & $\begin{array}{c}\text { No } \\
\text { lymphadenectomy }\end{array}$ & 2 weeks & 36 \\
\hline $\begin{array}{c}8 \\
(2009)\end{array}$ & 33 & 8 & $\begin{array}{l}\text { metrorrhagia } \\
\text { spontaneous } \\
\text { and post coital }\end{array}$ & $\begin{array}{c}\text { Moderately } \\
\text { differentiated } \\
\text { squamous }\end{array}$ & 5 & IIBproxi & $\begin{array}{l}\text { 1) TIP by laparotomy } \\
\text { 2) concomitant } \\
\text { radio-chemotherapy } \\
46 \mathrm{~Gy}, 2 \mathrm{~Gy} / \mathrm{fr}+ \\
\mathrm{CDDP} 40 \mathrm{mg} / \mathrm{m}^{2} \\
\text { and brachytherapy } \\
\text { HDR } 2 \times 7 \mathrm{~Gy}\end{array}$ & $\begin{array}{l}\mathrm{N}(\mathrm{p})+ \\
\mathrm{N}(\mathrm{Ao})-\end{array}$ & 2 weeks & 36 \\
\hline
\end{tabular}




\section{Continued}

\begin{tabular}{|c|c|c|c|c|c|c|c|c|c|c|}
\hline $\begin{array}{c}9 \\
(2010)\end{array}$ & 30 & 10 & $\begin{array}{l}\text { spontaneous } \\
\text { and post coital } \\
\text { metrorrhagia }\end{array}$ & $\begin{array}{l}\text { Moderately } \\
\text { differentiated } \\
\text { squamous }\end{array}$ & 3 & IIBproxi & $\begin{array}{l}\text { 1) TIP by laparotomy } \\
\text { 2) concomitant } \\
\text { radio-chemotherapy } \\
46 \mathrm{~Gy}, 2 \mathrm{~Gy} / \mathrm{fr}+ \\
\text { cisplatin } 40 \mathrm{mg} / \mathrm{m}^{2} \\
\text { and brachytherapy } \\
\text { HDR } 2 \times 7 \mathrm{~Gy}\end{array}$ & $\begin{array}{c}\mathrm{N}(\mathrm{p})+ \\
\mathrm{N}(\mathrm{Ao})-\end{array}$ & 2 weeks & $\begin{array}{c}24 \\
\text { pulmonary } \\
\text { Metastasis }\end{array}$ \\
\hline $\begin{array}{c}10 \\
(2010)\end{array}$ & 32 & 10 & $\begin{array}{l}\text { spontaneous } \\
\text { metrorrhagia } \\
+ \text { loss whitish }\end{array}$ & $\begin{array}{c}\text { Moderately } \\
\text { differentiated } \\
\text { squamous }\end{array}$ & $>4$ & IB2 & $\begin{array}{l}\text { 1) } \mathrm{TIP} \text {, concomitant } \\
\text { radio-chemotherapy } \\
46 \mathrm{~Gy}, 2 \mathrm{~Gy} / \mathrm{fr}+ \\
\text { cisplatin } 40 \mathrm{mg} / \mathrm{m}^{2} \\
\text { and brachytherapy } \\
\text { LDR } 24 \mathrm{~Gy}\end{array}$ & $\begin{array}{c}\text { No } \\
\text { lymphadenectomy }\end{array}$ & 3 weeks & 24 \\
\hline
\end{tabular}

Note: IIBproxi: IIB proximal; ADK: adenocarcinoma; LDR: low dose rate; HDR: high dose rate; IFOG: International Federation of Obstetrics Gynecology; TIP: therapeutic interruption of pregnancy; N (p) +: positive pelvic lymph node; N (Ao) -: negative paraaortic lymph node; WG: week of gestation.

\section{Toxicity:}

Acute side effects have been registered; it was grade 2 radiodermatitis in two cases, and diarrhea in three cases. These side effects have been treated symptomatically.

\subsection{Survival}

After 4 years median follow up (2 - 7), the local control rate was $100 \%$. The overall survival rate was $100 \%$. Bone and lung metastasis occurred at 2 years in patient $\mathrm{N}^{\circ} 9$.

\section{Discussion}

\subsection{Diagnostic}

The diagnosis of cervical cancer can be done by clinical signs. Spontaneous or post-coital metrorrhagia was observed in $43 \%$ to $54 \%$ of patients at early stages and in $81 \%$ of patients at advanced stages [7]. Spontaneous metrorrhagia was the reason for consultation in all our patients. Pelvic pain is observed mainly during advanced stages. These symptoms are frequently observed during pregnancy. The diagnosis can also be made in asymptomatic patients by cervical smears, in $20 \%-50 \%$ of the cases or even $76 \%$ according to the studies [8] [9]. This technique was not performed in our study, since the diagnosis was made at a late stage in all cases. In Sood et al. study, systematic cervical smears allowed the diagnosis of $60 \%$ of cervical cancer for pregnant women group against only $40 \%$ for non-pregnant women group [9]. Cervical smears with Cytobrush or spatula does not cause complications for pregnancy as well as colposcopy [10]. Biopsy is the most common way to confirm the diagnosis, with a low complication rate from $0.6 \%$ to $3 \%$ depending on the studies [7] [11]. These complications are essentially bleeding (exceptionally the risk of preterm labor) without complications. Endocervical curettage is contraindicated during pregnancy. Conization has a place apart; many studies have shown the maternal and fetal morbidity of 
this technique. There is a risk of hemorrhagic complication (5\% - 15\%), risk of preterm labor, of prematurity and third quarter infection and spontaneous abortion (25\%) (Predominant on the first and second quarters). Robova et al. have retained a case of spontaneous abortion on 23 patients who had a Conization between 13 and 23 WG, which represents a rate of 4\% [12]. In Demeter et al. study, on 48 patients who had Conization with cold knife highlights, two had late abortions at 21 WG (4\%) [13]. Fambrini et al., study shows that laser Conization performed at $18 \mathrm{WG}$ did not cause any fetal complications [14]. These three studies discussed curative treatment for in situ or microinvasive carcinomas. On there is a significant rate of residual lesion (more than 50\%) and positive margin during pregnancy [15]. Its only indication during pregnancy is for diagnosis, to confirm or invalidate the invasive disease because it changes the management time and the mode of delivery (Stage IA and IB1 differentiation). In this case, the optimal period for its realization is the second quarter between 14 and 20 WG because of the lower risk of complications [15]. In addition, Method et al., recommend superficial Conization to minimize cervical canal trauma and the use of many hemostatic sutures [16]. Colposcopy with guided biopsies is the choice technique in the diagnosis of cervical cancer during pregnancy (because of complications due to Conization). Note that the majority of retrospective studies did not show any difference in the distribution of histological types of cervical cancer in pregnant women compared to non-pregnant women (95\% squamous cell, 5\% adenocarcinoma [17] [18]). This is confirmed in our study.

\subsection{Assessment of Extension}

It is well known that ionizing radiation is deleterious to the fetus [19]. The recommended assessment of extension therefore includes an abdominal and pelvic ultrasound to evaluate the liver and the urogenital tract, an abdominal and pelvic MRI to determine tumor size, extension to neighboring organs and the existence of possible lymph node [1] [20] [21]. Ultrasound was the first examination in all our patients. PET exposes the fetus to $19 \mathrm{mGy}$ and could be examined if it is the only way to make the extension assessment of the disease [22]. Pulmonary radiography performed with fetal protection after the first quarter for locally advanced tumors $(\geq 4 \mathrm{~cm}$ ), and for high risk histological subtypes (adenocarcinoma, small cell cancer) [20]. Pulmonary radiography was performed in all our patients after hysterectomy. Once the diagnosis of invasive cancer is made, the question of the interruption or not of the pregnancy arises.

\subsection{Management of Cervical Cancer}

Regarding the management of pregnancy, Maurice et al. recommendations [6] based on the analysis of the literature and the experience of the participants, distinguish initially the period when fetal maturity can be considered attained: $28 \mathrm{WG}$, then the term authorizing nodal starifications: up to $24 \mathrm{WG}$ and finally FIGO stage. Five factors determine the therapeutic decision: the tumor 
stage, nodal status, histological subtype of the tumor term of pregnancy and the couple's desire to preserve pregnancy (Figure 1 and Figure 2).

- If the tumor is diagnosed at a term when fetal maturity could be considered attained

It is possible to preserve the fetus without delaying the treatment of the cervical cancer that should be performed, according to the standards of care, after the delivery. The term of delivery should be defined according to the term at the time of the diagnosis and to whether the tumor needs to be treated urgently (stage of the disease and tumor size). The delivery should be (optimally) performed using a cesarean section [23] [24] [25].

During this cesarean section, nodal staging surgery (pelvic nodes with or without paraaortic nodes for tumors greater than $4 \mathrm{~cm}$ or positive pelvic nodes) is recommended. Such staging procedure needs to be carried out by surgeons experienced in performing this oncologic surgical procedure. Ideally, the obstetrician and gynecologic oncologist should be present during this cesarean section.

Algorithm for tumors stage Ib1 diagnosed before fetal maturity Stage Ib1: lymphadenectomy possible?

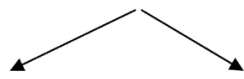

Before 20 - 24 WG
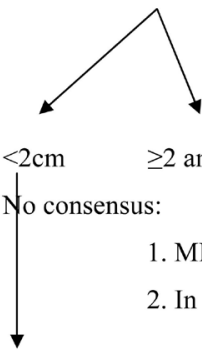

1. No MIP

. Pelvic lymph node dissection by laparoscopy

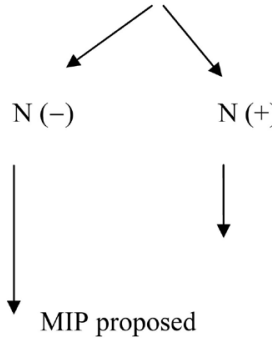

Chemo radiotherapy after MIP

Followed without immediate treatment: regular clinical examination, MRI/4 - 8 weeks, as soon as pulmonary maturity is reached, in the absence of tumor progression: Caesarean \pm Radical abdominal hysterectomy at the same time.

Figure 1. Algorithm for tumors stage IB1 diagnosed before fetal maturity. WG: Weeks of gestation; MIP: Medical interruption of pregnancy; N: Node. 
Algorithm for tumor size $\geq \mathbf{4} \mathrm{cm}$ diagnosed before fetal maturity

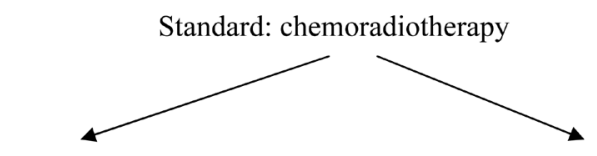

Before 22-24 WG

after 24 WG (and negative extension

assessment)

- Caesarean at the time of fetal maturity and aortic lymph node dissection

- Then chemoradiotherapy $\rightarrow$ either not more than 6-8 weeks after

diagnosis

Chemoradiotherapy

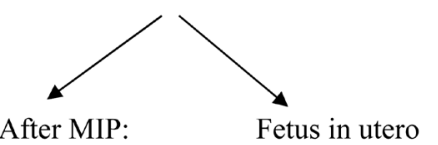

Hysterotomy

AVB

Figure 2. Algorithm for tumors of size $\geq 4 \mathrm{~cm}$ diagnosed before fetal maturity. WG: Week of gestation; MIP: Medical interruption of pregnancy; AVB: Vaginal delivery [42].

In multiparous women and in patients who do not wish to preserve their fertility, with stage IB1 disease, a radical hysterectomy can be associated with nodal surgery at the time of the cesarean section [9] [18] [26] [27].

- If the tumor is diagnosed before the term when fetal maturity is attained (between 26 and $30 \mathrm{WG}$ ) in a patient wishing to preserve the fetus (tumor with a usual histological subtype and exclusion of small cell carcinoma or a similar aggressive tumor).

$\checkmark$ Stage IB1 disease diagnosed before 18 to 22 WG (term when pelvic laparoscopic lymphadenectomy is still technically feasible).

\section{Stage IB1 and tumor size less than $2 \mathrm{~cm}$}

The pregnancy is not being interrupted at this point. An initial laparoscopic pelvic lymphadenectomy is recommended [28]. As this is a crucial procedure, it should be performed by surgeons trained to such procedure in pregnant patients.

*Absence of nodal involvement: In this case, the patient is followed up without immediate treatment of the cervical tumor. This follow-up procedure should include a clinical examination and imaging (MRI every 4 to 8 weeks, but there is no consensus among experts concerning the frequency of MRI) [29]. In the absence of disease progression, curative treatment of the cervical tumor should begin as soon as fetal maturity is attained [7] [9]. The delivery route should be cesarean section [23] and the cervical tumor should be treated according to the standards of care. Radical hysterectomy can be performed at the time of cesarean section [18] [26] [27].

${ }^{*}$ Presence of nodal involvement: In this case, interruption of the pregnancy 
should be recommended to the patient, and the standard management is chemoradiation therapy (after the uterus is empty). The radiation therapy fields depend on the highest level of nodal involvement (pelvic nodes alone or pelvic and paraaortic nodes). The status of paraaortic nodes can be determined by performing a laparoscopic paraaortic lymphadenectomy or positron emission tomography imaging (carried out after pregnancy interruption). The choice between these 2 procedures will depend on the team administering treatment and on whether the surgeons have experience with laparoscopic paraaortic lymphadenectomy.

\section{Stage IB1 disease with a tumor size between 2 and $4 \mathrm{~cm}$}

It is impossible to define a standard management policy in such a situation, and each case should be discussed separately. The risk of nodal involvement is significantly higher than in patients with a tumor measuring less than $2 \mathrm{~cm}$ so pregnancy interruption is the first option that should be discussed with the patient (particularly if the tumor is discovered during the first trimester). If the patient refuses this option, management could be similar to that of patients with a tumor measuring less than $2 \mathrm{~cm}$.

$\checkmark$ In stage IB1 disease diagnosed after 18 to 22 WG (for which laparoscopic lymphadenectomy is not technically feasible, even in the hands of experienced surgeons).

\section{Stage IB1 and tumor size less than $2 \mathrm{~cm}$}

Careful follow-up should be conducted including clinical and radiological imaging (in the absence of suspicious lymph nodes on initial imaging). The clinician should explain to the patient the oncologic uncertainty in such a situation, namely, the potential risk of increasing the recurrence rate while awaiting fetal maturity. Curative treatment of the cervical tumor should be initiated once fetal maturity has been attained. The presence of a malignant tumor is not a contraindication to the use of neonatal corticoids to increase fetal chest maturity.

The delivery route should be a cesarean section, and the cervical tumor should be treated according to the standards of care. A radical hysterectomy with pelvic lymphadenectomy can be performed at the time of cesarean section.

\section{Stage IB1 with a tumor size between 2 and $4 \mathrm{~cm}$}

It is impossible to define a standard management policy in such a situation; therefore, each case should be discussed individually. If the term when the tumor is diagnosed is very close to the term when fetal maturity is attained, the management can be similar to that of patients with a tumor measuring of less than 2 $\mathrm{cm}$.

Particularly if the tumor size is close to $4 \mathrm{~cm}$, the other option that could be discussed is the use of neoadjuvant chemotherapy (confers chapter neo adjuvant chemotherapy). However, the patient should be informed of the uncertainty regarding the oncologic and fetal outcomes of such management.

\section{Patients with tumor greater than $4 \mathrm{~cm}$}

The standard management in France in such patients is based on chemoradia- 
tion therapy. If the tumor is discovered before 20 to 22 WG (no consensus between experts regarding this term), chemoradiation therapy should be delivered either after the uterus is empty (using a hysterotomy or another procedure [30], or with the fetus in utero if its expulsion seems to be impossible (bulky cervical cancer) [21] [31]. This chemoradiation therapy should be delivered (in terms of doses and type of concomitant chemotherapy and radiation therapy fields) according to the usual standards in such a situation.

If the tumor is diagnosed after $22 \mathrm{WG}$ (in the absence of extra cervical spread detected at the radiological examination), chemoradiation can be started after the caesarean delivery, which should be performed once fetal maturity has been attained (provided such management will not delay the start of tumor treatment for $>6-8$ weeks). During this caesarean section, paraaortic staging surgery is recommended (if such surgery is performed by a surgeon who has experience performing this procedure).

Another option could be discussed in such situation in patients wishing to preserve the viability of their fetus: the use of neoadjuvant chemotherapy. It should be discussed only if the tumor is diagnosed after 18 to 20 WG. The patient should receive a clear explanation regarding the potential risk of rapid progression (potentially lethal for the patient) of the disease reported in several cases after such management in the literature [32] [33] and (2) the uncertainty concerning the long-term effects of neoadjuvant chemotherapy on the fetus.

- Patients with more aggressive histological subtype (small cell carcinoma or a similar unusual tumor) diagnosed during the first or second trimester of pregnancy.

In such situation, each case should be discussed individually, but pregnancy preservation is not recommended because treatment of the tumor is regarded as an oncologic emergency.

\section{Therapeutic option for maintaining pregnancy}

Neoadjuvant chemotherapy in advanced cervical cancer causes the regression of tumor size and is considered a promising technique in curative management [34]. But, the use of this technique during pregnancy is controversial since its impact on growth and fetal health is poorly understood and potentially dangerous. Indeed, the existing data on this subject are few. The molecule most used in chemotherapy is cisplatin and most cases reported during pregnancy relate to its use. A recent review published by Cochin team [35] in November 2008 listed all publications concerning the use of cisplatin during pregnancy from 1977 to February 2008: forty-five publications have been identified, forty-three patients were retained in the observation, thirty six patients received cisplatin and only six received cisplatin alone. Two fetal malformations were found (ventriculomegaly and microphthalmia), but hardly attributable to the use of cisplatin. Nephrological and hematological toxicity (one case of transient neonatal renal failure and four cases of cytopenia) have been found with cisplatin, but it should be noted that information concerning these parameters was missing for a number of children. For carboplatin, six patients who received treatment were identi- 
fied, three received carboplatin alone. No severe maternal toxicity was found (grade 3 - 4 according to the classification of National Cancer Institute Common Toxicity Criteria version 2.0) and any fetal malformation or neonatal toxicity. The feasibility of using platinum salts during the second and third quarter of pregnancy is retained with the following reserves: no long-term follow-up published in children exposed in utero and studies often combining several chemotherapy.

Tewari et al., in 1997, presented two cases treated with vincristine and cisplatin during pregnancy at 34 and 36 WG, with stages IIA and IB respectively [32]. In both patients, the reduction of tumor size has been demonstrated, and the children did not show any side effects. The first patient died 13 months later and the second patient is in remission. One case is described by Van Calsteren et al., it is a stage IB1 diagnosed at $15 \mathrm{WG}$ and treated with six different regimes of cisplatin at $17 \mathrm{WG}$, thrombocytopenia was recorded [36]. The baby was born by caesarean section to $32 \mathrm{SA}$ in good health, eutrophic, and at six months his psychomotor development, the hearing test, cardiac, neurological examination, and his growth were normal. The histological study did not show any progression of the tumor size or lymph node invasion. Administration of chemotherapy is contraindicated during the period of organogenesis, up to 13 WG [37]. Doll et al., described possible fetal complications when using chemotherapy during the last two quarter of pregnancy: intrauterine growth retardation stillborn, prematurity, impaired mental development, teratogenicity, low birth weight, spontaneous abortion and maternal infertility [37]. But the anomaly rate at birth when exposure is made in the second and third quarter and is similar to that of the general population $(1 \%-3 \%)[1]$.

Data from the cisplatin exposure literature during pregnancy are also very low. Out of 21 reported cases, two had intrauterine growth retardation; a patient had bilateral partial deafness, and one last patient had idiopathic ventricular dilatation with neurologic sequeals [20]. When this treatment is administered, delivery should be scheduled three to four weeks after the last course of treatment to allow the fetal bone marrow to regenerate [20]. When this treatment is administered, delivery should be scheduled three to four weeks after the last chemotherapy cycle to allow the fetal bone marrow to regenerate [20]. Chemotherapy should not be administered after 35 weeks because of the risk of causing spontaneous childbirth. In addition, an assumption was raised by Polish and Twiggs in 1993, the possibility of selection of resistant cells by this neoadjuvant chemotherapy [27]. The absence of cases in the literature does not establish the safety and efficacy of neoadjuvant chemotherapy. But when a patient refuses the sacrifice of her pregnancy, this therapy can be an alternative, in order to wait for fetal viability, stabilizing the disease. It poses an ethical problem that requires the opinion of a multidisciplinary commission.

\subsection{Diagnosis-Treatment Delay}

Diagnosis-treatment time is the time elapsed in weeks between the diagnosis of 
cervical cancer and the main treatment; this delay is one of the main points to consider. In our series the median time was 3 weeks ( 2 to 8 ). Karam et al., in 2007 listed all published studies concerning treatment postponement times for patients with invasive cervical cancer diagnosed during pregnancy and wishing to continue the pregnancy, delays ranged from 3 to 40 weeks [38].

\subsection{Prognosis of Cancer during Pregnancy}

Some retrospective studies [39] have shown poorer survival in patients with cervical cancer during pregnancy compared to non-pregnant patients at the same stage. The hypothesis, to explain these results, was the clinical underestimation of the stage of the disease, because the appreciation of the extension to the parameters by the clinical examination is more difficult during the pregnancy because of ligaments hyperextension [40]. The link between the time of diagnosis during pregnancy and survival is controversial. Most studies show no difference in survival [41] even after stratification by stages and quarter of discovery [11].

\subsection{Encountered Difficulties}

In our series, the diagnosis was made in regional centers of gynecology; under duress, the initial therapeutic attitude did not often meet the recommendations (desire of the couple not to maintain the pregnancy and tumor size $>5 \mathrm{~cm}$ ). All patients were referred for further management.

\section{Conclusion}

Our series focused on ten patients with invasive cervical cancer during pregnancy. Management is complex and requires discussion in a multidisciplinary meeting. Routine screening of cervical cancer and awareness are the key point to improve the treatment and survival rate of patients. The management of all cases isaccording to international recommendations.

\section{Consent}

As per international standard or university standard, patient's written consent has been collected and preserved by the authors.

\section{Ethical Approval}

All authors hereby declare that all experiments have been examined and approved by the appropriate ethics committee and have therefore been performed in accordance with the ethical standards laid down in the 1964 Declaration of Helsinki.

\section{Conflicts of Interest}

Authors have declared that no competing interests exist. 


\section{References}

[1] Pavlidis, N.A. (2002) Coexistence of Pregnancy and Malignancy. Oncologist, 7, 279-287. https://doi.org/10.1634/theoncologist.7-6-573

[2] Lee, R.B., Neglia, W. and Park, R.C. (1981) Cervical Carcinoma in Pregnancy. Obstetrics and Gynecology, 58, 584.

[3] Duggan, B., Muderspach, L.I., Roman, L.D., et al. (1993) Cervical Cancer in Pregnancy: Reporting on Planned Delay in Therapy. Obstetrics and Gynecology, 82, 598.

[4] Pettersson, B.F., Andersson, S., Hellman, K. and Hellström, A.-C. (2010) Invasive Carcinoma of the Uterine Cervix Associated with Pregnancy: 90 Years of Experience. Cancer, 116, 2343-2349. https://doi.org/10.1002/cncr.24971

[5] Zemlickis, D., Lishner, M., Degendorfer, P., et al. (1991) Maternal and Fetal Outcome after Invasive Cervical Cancer in Pregnancy. Journal of Clinical Oncology, 9 , 1956-1961. https://doi.org/10.1200/JCO.1991.9.11.1956

[6] Morice, P., Narducci, F., Mathevet, P., et al. (2009) French Recommendations on the Management of Invasive Cervical Cancer during Pregnancy. International Journal of Gynecological Cancer, 19, 1638-1641. https://doi.org/10.1111/IGC.0b013e3181a83017

[7] Jones, W.B., Shingleton, H.M., Russel, A., et al. (1996) Cervical Carcinoma and Pregnancy: A Patterns of Care of the American College of Surgeons. Cancer, 77, 1479-1488.

https://doi.org/10.1002/(SICI)1097-0142(19960415)77:8<1479::AID-CNCR9>3.0.C $\underline{\mathrm{O} ; 2-7}$

[8] Germann, N., Haiemeder, C., Morice, P., et al. (2005) Management and Clinical Outcomes of Pregnant Patients with Invasive Cervical Cancer. Annals of Oncology, 16, 397-402. https://doi.org/10.1093/annonc/mdi084

[9] Sood, A.K., Sorosky, J.I., Krogman, S., et al. (1996) Surgical Management of Cervical Cancer Complicating Pregnancy: A Case-Control Study. Gynecologic Oncology, 64, 294. https://doi.org/10.1006/gyno.1996.0325

[10] Woodrow, N., Permezel, M., Butterfield, L., et al. (1998) Abnormal Cervical Cytology in Pregnancy: Experience of 811 Cases. The Australian \& New Zealand Journal of Obstetrics \& Gynaecology, 38, 161-165. https://doi.org/10.1111/j.1479-828X.1998.tb02992.x

[11] Nguyen, C., Montz, F.J. and Bristow, R.E. (2000) Management of Stage I Cervical Cancer in Pregnancy. Obstetrical \& Gynecological Survey, 55, 633. https://doi.org/10.1097/00006254-200010000-00022

[12] Robova, H., Rob, L., Pluta, M., et al. (2005) Squamous Intraepithelial Lesion-Microinvasive Carcinoma of the Cervix during Pregnancy. European Journal of Gynaecological Oncology, 26, 611-614.

[13] Demeter, A., Sziller, I., Csapo, Z., Szantho, A. and Papp, Z. (2002) Outcome of Pregnancies after Cold-Knife Conization of the Uterine Cervix during Pregnancy. European Journal of Gynaecological Oncology, 23, 207-210.

[14] Fambrini, M., Penna, C., Fallani, M.G., et al. (2007) Feasibility and Outcome of Laser $\mathrm{CO}_{2}$ Conization Performed within the 18th Week of Gestation. International Journal of Gynecological Cancer, 17, 127-131. https://doi.org/10.1111/j.1525-1438.2007.00802.x

[15] Hannigan, E.V., Whitehouse, H.H., Atkinson, W.D. and et Becker, S.N. (1982) 
Cone Biopsy during Pregnancy. Obstetrics and Gynecology, 60, 450-455.

[16] Method, M.W. and Brost, B.C. (1991) Management of Cervical Cancer in Pregnancy. Seminars in Surgical Oncology, 16, 251-260.

https://doi.org/10.1002/(SICI)1098-2388(199904/05)16:3<251::AID-SSU11>3.0.CO; $\underline{2-4}$

[17] Smith, L., Danielsen, B., Allen, M. and Cress, R. (2003) Cancer Associated with Obstetric Delivery: Results of Linkage with the California Cancer Registry. American Journal of Obstetrics \& Gynecology, 189, 1128-1135. https://doi.org/10.1067/S0002-9378(03)00537-4

[18] Sivanesaratnam, V., Jayalakshmi, P. and Loo, C. (1993) Surgical Management of Early Invasive Cancer of the Cervix Associated with Pregnancy. Gynecologic Oncology, 48, 68-75. https://doi.org/10.1006/gyno.1993.1011

[19] Vincens, C., et al. (2008) Prise en charge des volumineux cancers invasifs du col de l'utérus pendant la grossesse. Gynécologie Obstétrique \& Fertilité, 36, 365-3723. https://doi.org/10.1016/j.gyobfe.2007.12.018

[20] Van Calsteren, K., Vergote, I., Amant, F., et al. (2005) Cervical Neoplasia during Pregnancy: Diagnosis, Management, and Prognosis. Best Practice \& Research: Clinical Obstetrics \& Gynaecology, 19, 611-630. https://doi.org/10.1016/j.gyobfe.2007.12.018

[21] Prem, K.A., Makowski, E.L. and Mc Kelvey, J.L. (1966) Carcinoma of the Cervix Associated with Pregnancy. American Journal of Obstetrics \& Gynecology, 95, 99-108. https://doi.org/10.1016/0002-9378(66)90634-X

[22] Zanotti-Fregonara, P., Champion, C., Trebossen, R., et al. (2008) Estimation of the Beta+ Dose to the Embryo Resulting from 18F-FDG Administration during Early Pregnancy. Journal of Nuclear Medicine, 49, 679-682 https://doi.org/10.2967/jnumed.107.048900

[23] Sood, A.K., Sorosky, J.I., Mayr, N., et al. (2000) Cervical Cancer Diagnosed Shortly after Pregnancy: Prognostic Variables and Delivery Routes. Obstetrics \& Gynecology, 95, 832-838. https://doi.org/10.1097/00006250-200006000-00010

[24] Copeland, L.J., Saul, P.B. and Sneige, N. (1987) Cervical Adenocarcinoma: Tumor Implantation in the Episiotomy Sites of Two Patients. Gynecologic Oncology, 28, 230-235. https://doi.org/10.1016/0090-8258(87)90219-8

[25] Khalil, A.M., Khatib, R.A., Mufarrij, A.A., et al. (1993) Squamous Cell Carcinoma of the Cervix Implanting in the Episiotomy Site. Gynecologic Oncology, 51, 408-410. https://doi.org/10.1006/gyno.1993.1313

[26] Monk, B.J. and Montz, F.J. (1992) Invasive Cervical Cancer Complicating Intrauterine Pregnancy: Treatment with Radical Hysterectomy. Obstetrics \& Gynecology, 80, 199-203.

[27] Thompson, J.D., Caputo, T.A., Franklin III, E.W. and Dale, E. (1975) The Surgical Management of Invasive Cancer of the Cervix in Pregnancy. American Journal of Obstetrics \& Gynecology, 121, 853-863. https://doi.org/10.1097/00006254-197508000-00008

[28] Alouini, S., Rida, K. and Mathevet, P. (2008) Cervical Cancer Complicating Pregnancy: Implications of Laparoscopic Lymphadenectomy. Gynecologic Oncology, 108, 472-477. https://doi.org/10.1016/j.ygyno.2007.12.006

[29] Zanetta, G., Pellegrino, A., Vanzulli, A., et al. (1998) Magnetic Resonance Imaging of Cervical Cancer in Pregnancy. International Journal of Gynecological Cancer, 8, 265-269. https://doi.org/10.1046/j.1525-1438.1998.09802.x 
[30] Ostrom, K., Ben-Arie, A., Edwards, C., et al. (2003) Uterine Evacuation with Misoprostol during Radiotherapy for Cervical Cancer in Pregnancy. International Journal of Gynecological Cancer, 13, 340-343. https://doi.org/10.1046/j.1525-1438.2003.13198.x

[31] Creasman, W.T., Rutledge, F.N. and Fletcher, G.H. (1970) Carcinoma of the Cervix Associated with Pregnancy. Obstetrics \& Gynecology, 36, 495-501.

[32] Tewari, K., Cappuccini, F., Gambino, A., et al. (1998) Neoadjuvant Chemotherapy in the Treatment of Locally Advanced Cervical Carcinoma in Pregnancy: A Report of Two Cases and Review of Issues Specific to the Management of Cervical Carcinoma in Pregnancy Including Planned Delay of Therapy. Cancer, 82, 1529-1534. https://doi.org/10.1002/(SICI)1097-0142(19980415)82:8<1529::AID-CNCR15>3.0.C O;2-6

[33] Benhaim, Y., Pautier, P., Bensaid, C., et al. (2008) Neoadjuvant Chemotherapy for Advanced Stage Cervical Cancer in a Pregnant Patient: Report of 1 Case with Rapid Tumor Progression. European Journal of Obstetrics \& Gynecology and Reproductive Biology, 136, 267-268. https://doi.org/10.1016/j.ejogrb.2006.10.027

[34] Ferrer, C., Dupaigne, D., de Tayrac, R., et al. (2006) Traitement des cancers volumineux du col utérin de stades I et II. Encyclopédie Médico-chirurgicale.

[35] Mir, O., Berveiller, P., Ropert, S., Goffinet, F. and Goldwasser, F. (2008) Use of Platinum Derivatives during Pregnancy. Cancer, 113, 3069-3074.

https://doi.org/10.1002/cncr.23935

[36] Caluwaerts, S., Van Calsteren, K., Mertens, L., et al. (2006) Neoadjuvant Chemotherapy Followed by Radical Hysterectomy for Invasive Cervical Cancer Diagnosed during Pregnancy: Report of a Case and Review of the Literature. International Journal of Gynecological Cancer, 16, 905-908. https://doi.org/10.1111/j.1525-1438.2006.00223.x

[37] Doll, D.C., Ringenberg, Q.S. and Yarbro, J.W. (1989) Anti-Neoplastic Agents and Pregnancy. Seminars in Oncology, 16, 337-346.

[38] Karam, A., Feldman, N. and Holschneider, C.H. (2007) Neoadjuvant Cisplatin and Radical Cesarean Hysterectomy for Cervical Cancer in Pregnancy. Nature Clinical Practice Oncology, 4, 375-380. https://doi.org/10.1038/ncponc0821

[39] Bokhman, J.V., Badikoze, E.V. and Ourmancheeva (1997) Fertility, Pregnancy and Cancer. Acta Obstetricia et Gynecologica Scandinavica, 164, 148.

[40] Zoundi-Ouango, O., Morcel, K., Classe, J.M., Burtin, F., Audrain, O. and Leveque, J. (2006) Lésions cervicales utérines pendant la grossesse: Diagnostic et prise en charge. Journal de Gynécologie Obstétrique et Biologie de la Reproduction, 35, 227-236. https://doi.org/10.1016/S0368-2315(06)78306-5

[41] Creasman, W.T. (2001) Cancer and Pregnancy. Annals of the New York Academy of Sciences, 943, 281-286. https://doi.org/10.1111/j.1749-6632.2001.tb03809.x

[42] Carillon, M.-A., Emmanuellib, V., Castelaina, B., et al. (2011) Cancer du col utérin invasif et grossesse. Journal de Gynécologie Obstétrique et Biologie de la Reproduction, 40, 514-521. https://doi.org/10.1016/j.jgyn.2011.06.015 